\title{
Role-Playing Model on Speaking Skill for Elementary School Students
}

\section{Lutfiana Ristianisa ${ }^{1 *}$, Suhardi ${ }^{2}$}

\author{
1,2 Program Studi Pendidikan Dasar, Pascasarjana, Universitas Negeri Yogyakarta, Yogyakarta, Indonesia
}

\section{ART I CLE I N F O}

\section{Article history:}

Received January 21, 2021

Revised February 03, 2021

Accepted April 08, 2021

Available online May 25, 2021

Kata Kunci:

Model Pembelajaran, Banjarnegara Pendidikan, Pengajaran

Keywords:

Learning Models, Banjarnegara Education, Teaching

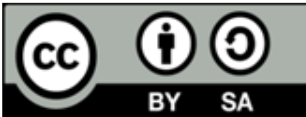

This is an open access article under the CC BY-SA license.

Copyright $(2021$ by Author. Published by Universitas Pendidikan Ganesha.

\begin{abstract}
A B S T R A K
Kurangnya kreatifitas dan keterampilan berbicara Bahasa Indonesia pada guru kelas IV di beberapa Sekolah Dasar (SD) secara langsung memberikan dampak yang langsung terhadap proses pembelajaran Bahasa Indonesia di kelas. Proses pembelajaran mata pelajaran Bahasa Indonesia masih disampaikan dengan campuran bahasa ibu atau bahasa daerah sehari-hari. Tujuan penelitian ini adalah menganalisi pengaruh signifikan model role playing terhadap keterampilan berbicara bahasa Indonesia kelas IV SD. Jenis penelitian adalah penelitian eksperimen semu (quasi eksperiment) menggunakan pendekatan kuantitatif. Populasi dalam penelitian ini adalah seluruh kelas IV SD yang terdiri 7 sekolah dasar. Proses pengambilan sampel menggunakan teknik purposive sampling yang artinya pemilihan kelas eksperimen dan control. Metode pengambilan data dengan observasi lapangan dan wawancara secara langsung. Hasil penelitian menunjukkan pada variabel keterampilan berbicara bahasa Indonesia siswa diperoleh nilai $F_{\text {hitung }}$ sebesar 81,352 dan $p=0$,000. Maka dapat disimpulkan bahwa terdapat pengaruh yang signifikan penerapan pebelajaran kooperatif tipe role playing terhadap keterampilan berbicara bahasa Indonesia siswa kelas IV SD. Temuan penelitian ini akan memberikan implikasi untuk meningkatkan keterampilan berbicara bahasa Indonesia siswa.
\end{abstract}

\begin{abstract}
A B S T R A C T
The lack of creativity and skills to speak Bahasa Indonesia in grade IV teachers in some elementary schools directly impacts the learning process of Bahasa Indonesia in the classroom. The learning process of Bahasa Indonesia lessons was still delivered with a mixture of mother tongue or daily regional language. The purpose of this study was to explore the significant influence of role-playing models on Indonesian language speaking skills in grade IV elementary school. This type of research was pseudo-experimental research (quasi-experimental) using a quantitative approach. The population in this study was the entire fourth grade of elementary school consisting of 7 elementary schools. The sampling process used the purposive sampling technique, which meant selecting experimental and control classesthe method of extracting data with field observations and live interviews. The results showed on the variable Indonesian language speaking skills; students obtained a value of $F_{\text {count }}$ was 81,352 and $p=0,000$. So it can be concluded that there is a significant influence on applying role-playing type cooperative learning to the Bahasa speaking skills of grade IV elementary school students. The findings of this study will have implications for improving students' Bahasa speaking skills.
\end{abstract}

\section{INTRODUCTION}

Bahasa Indonesia is a national language used by Indonesian citizens with various languages based on ethnicity and culture to socialize with each other in the national sphere (Nita, 2019; A.M. Rambe et al., 2021). Therefore, Bahasa Indonesia is the main subject taught by elementary school students ranging from grade I to grade VI. Indonesian language lessons aim to allow students to have the ability, among other things, communicating effectively and efficiently following the ethics that apply both verbally and in writing, appreciate and proudly use the Language of Indonesia as a language of unity, understand The Indonesian language and use it appropriately and creatively for various purposes, use Bahasa Indonesia for intellectual ability, as well as emotional maturity, and social, enjoy and utilize literary works to broaden insights, expand ethics, and improve knowledge, and language skills and appreciate and pride Indonesian literature as a cultural and intellectual characteristic of Indonesian people (Aditya Dharma, 2019; R. N. K. Rambe, 2018).

Language skills that must be developed, among others, are listening, reading, writing, and last speaking (Korsgaard et al., 2020; Lim \&Polio, 2020; Nungki Heriyati, Riris K. Sarumpaet, 2020; Thanksgiving et al., 2020). Teachers should deliver these four skills with interesting learning strategies to develop students' understanding and skills well. Teachers plan lessons and develop new skills and 
methods and make students more interested (Lubis, 2020; Priyantini, 2020). Teachers should focus not only on one aspect of learning but also on every aspect because one aspect of skills will support the skills. One of the basic skills that students must have is speaking skills. Speaking skills are essential for a learner to conduct communication activities politely and effectively (Ariani, 2020; Mishbah et al., 2020). The lack of skill in a person speaking can lead to a lack of maximum social relations. Learning to speak in elementary school aims to allow students to express their thoughts, feelings and information following the context (Chan et al., 2019).

However, based on the fact of observations with some grade IV elementary school teachers in Wanadadi sub-district, Banjarnegara district, some problems are found related to creativity and Bahasa speaking skills of grade IV elementary school students, namely the lack of knowledge of teachers will be various models and methods of learning as well as techniques and strategies of learning that they can use. It is causing education that lasts more monotonous and ordinary centered on teachers so that students look bored and inactive and inactive in the learning process. The location of the Wanadadi subdistrict is pretty on the outskirts of Banjarnegara city. With the environmental conditions that are still traditional and with the colloquial language used is the mother tongue or the language of Javanese, teachers do not use Indonesian and still use the regional language in carrying out the learning process so that students are less accustomed to Indonesian. Lack of habituation using Bahasa, especially when running the learning process, students tend to have difficulty still speaking using good Indonesian. As well as the research conducted (Muthmainnah, 2018) in class action research (PTK) showed in pre-action, the percentage of completion of students is $12.5 \%$, with an average score of 5.49. After the first cycle of action, the completion percentage reached $52.63 \%$, with an average value of 7.11 . In cycle II, the completion rate also increased to $84.21 \%$, with an average value of 8.06 .

The condition proves that the use of learning models in teaching and learning activities is less varied. Some teachers do not use existing learning models because they find it challenging to apply the model in learning. Therefore, this learning needs to be involved in an attractive learning model and can support learning activities. The learning model is a structural framework as a guide to developing a conducive environment and learning activities (Diah Purwati et al., 2019). The solution that can be offered is to use the role-playing learning model. Model role-playing learning is to develop the learning skills of Indonesian language students (Kristiana, 2020). Using the role-playing method will make students active because they are directly involved in the subject. It can make students interested in the material or a subject (Setiawan, 2019; Wahyuni et al., 2018). In addition to attracting students to the subjects, students' Indonesian speaking skills will also increase due to using these methods to provoke and train students' speaking skills by practicing directly according to the given role (Kristin, 2018). Roleplaying students can directly enter the communication activities using Bahasa Indonesia to develop their Indonesian language usage skills. Metode role-playing done by playing someone or something can make students easier to understand and live the material's content as a whole (Hussain, 2017). Such methods will also actively involve students in the learning process to improve the quality of the learning process.

The steps in applying role-playing include (1) The teacher composing or preparing the scenario to be displayed; (2) Teachers form student groups; (3) Provide an explanation of the competencies to be achieved; (4) Call the designated students to perform the prepared scenario; (5) Each group shall present its conclusions; and (6) Teachers give conclusions in general (Wahyuni et al., 2018). Previous research findings suggest role-playing models can help learners understand the feelings shared by others, tepa seliro, and tolerance (Kristiana, 2020). In addition, role-playing aims to enable students to live the desired role because the success of students in living the role will be obtained understanding, appreciation, and self-identification of the value that develops (Sulianto et al., 2019; Wahyuni et al., 2018). Many previous studies have applied role-playing models. Still, the application of role-playing models to improve speaking skills in grade IV elementary schools in the Wanadadi subdistrict has never been applied. Fun learning will help students be active in the learning process. Learning with the appropriate model can facilitate students in understanding learning materials and stimulate the language security of students. The application of the role-playing learning model is oriented to students' learning process to improve speaking Bahasa Indonesia's skills. Thisnelitian hypothesis is that there is a significant influence of the role-playing model on the Indonesian language speaking skills of grade IV students of SD Cluster I Ki Hajar Dewantara

\section{METHOD}

This research used a quantitative approach with pseudo experimental research type (quasi experimentation). It was said to be pseudo because not all factors outside the variables studied were fully controlled. Pseudo-experimental research involves the use of subject groups in their entirety. In this 
study, researchers did not create new classes but used classes as they were. The study included three groups of students, two groups who were treated with role-playing learning models as an experimental group and one group that was not treated with a role-playing type model as a control group. The research aimed to analyze the influence of the role-playing learning model on students' Indonesian speaking skills. The research design used in this study was Randomized Pretes-Postes Control-Group. The design of this research was presented in Table 01. According to the design, the two groups were given the same initial test. After being given the initial test, both experimental groups were treated in the form of role-playing learning models. Although the control group did not receive treatment, this did not mean that they received no experience at all. In this study, the control group was treated by conventional learning. After the experimental group was treated, students were then given a final test. Similarly, the control group was given the same final test. The results of the initial and final tests in each group were compared (tested the difference), a significant difference between the initial test results and the final test of both groups showed the influence of the treatment given. Data collection was in the form of a table with a description consisting of $\mathrm{O}_{1}$ was a pre-test of the experimental group; $\mathrm{O}_{2}$ was a post-test group of experiments; $\mathrm{O}_{3}$ was a pre-test control group; $\mathrm{O}_{4}$ was a post-test control group; $\mathrm{X}_{\mathrm{T}}$ is the treatment of using role-playing learning model; and $\mathrm{X}_{\mathrm{C}}$ is the treatment of not using role-playing learning model.

This research was conducted in Wanadadi Subdistrict, Banjarnegara Regency, which consists of 16 elementary schools. The reason for the selection of this research place was because elementary schools in the Wanadadi subdistrict were still many teachers who have not implemented learning by applying innovative learning models such as Role-playing models. The research time was conducted in the second semester of the 2017/2018 school year. This research was conducted in March-April 2018. The population in this study was the entire grade IV elementary school in Cluster I Ki Hajar Dewantara, Wanadadi Subdistrict in the 2017/2018 school year consisting of 7 elementary schools, namely SDN 1 Wanadadi, SDN 2 Wanadadi, SDN Tapen, SDN Karangjambe, SDN 1 Kasilib, SDN 2 Kasilib, and SDN 3 Kasilib. The sampling process in this study used the purposive sampling technique, which meant that the selection of experimental and control classes was determined based on certain predetermined characteristics. The selected class had relatively similar characteristics, both from the rest and teachers who tend to have similar academic qualifications so that it can be said to be homogeneous. The experimental class was grade IV SD Karangjambe and SD Wanadadi, and the control class is grade IV SD Tapen.

This study's data collection techniques were (a) assessment of speech skills performance, namely compiling research performances to reveal speaking skills before and after treatment. Data collection using performances conducted according to variables tied from the research of speaking skills. (b) documentation, This study used documentation in the form of photos to record various events in the learning process. In addition, the lesson plan was used as the evidence of the design of the learning process used in the research. The data collection instrument conducted by this study was a collection of performance assessment sheets. The demonstration was conducted when students conducted speaking lessons in front of the class. Scoring uses five alternative answers because it uses the Likert scale measurement technique. Here was the format of the student's speaking assessment sheet.

Table 1. Reasearch Planning

\begin{tabular}{rll}
\hline \multicolumn{1}{c}{ No } & \multicolumn{1}{c}{ Rated Aspect } & \multicolumn{1}{c}{ Component } \\
\hline 1. & Pronunciation & Phoneme pronunciation, influence of original dialect, volume \\
2. & Word Choice & Politeness of words choice, ambiguous or not, hurting others or \\
3. & Fluency & not, conformity to the topic \\
4. & Intonation and pause & Fluency of speech, stuttering or not, suitability of pause \\
5. & Topic & Pause placement, tone and intonation \\
6. & Confident & Suitability of the topic spoken, the demand of the conversation \\
\hline
\end{tabular}

\section{RESULT AND DISCUSSION}

This research has some data, namely pre-test and post data of Bahasa speaking skills test. The data was obtained from a sample of research, namely all students of grade IV in group I Ki Hajar Dewantara in the 2017/2018 school year consisting of 6 elementary schools, namely SDN 1 Wanadadi, SDN 2 Wanadadi, SDN Karangjambe, SDN 1 Kasilib, SDN 2 Kasilib, and SDN 3 Kasilib. One school as an experimental class and one school as a control class. The experimental classes were SDN 3 Kasilib and 
SDN Karangjambe as control classes. The practical class was given the same treatment, first offered a pretest, then given treatment using role-playing learning, and at the end of the treatment was given a posttest. Both groups get the same learning materials in the implementation While in the control class using conventional models with lecture methods.

Table 2. Pre-test and Post-test Results Bahasa Speaking Skill of Control and Experiment Group

\begin{tabular}{lcccc}
\hline \multirow{2}{*}{ Analyst Results } & \multicolumn{2}{c}{ Control } & \multicolumn{2}{c}{ Experiment } \\
\cline { 2 - 5 } & Pre-test & Post-test & Pre-test & Post-test \\
\hline Mean & 53,64 & 65,50 & 52,33 & 73,79 \\
Median & 54,50 & 66,00 & 50,00 & 73,50 \\
Mode & 56,00 & 66,00 & 56,00 & 66,00 \\
Std. Deviation & 4,304 & 7,386 & 4,613 & 7,706 \\
Max. score & 63,00 & 80,00 & 53,00 & 85,00 \\
Min. score & 47,00 & 50,00 & 47,00 & 59,00 \\
\hline
\end{tabular}

A descriptive analysis of the Bahasa speaking skills of control class students who received treatment using lecture methods showed that the average maximum pre-test value of the control class was 63.00 , and the minimum score was 47.00 . The average pre-test score in the control class was 53.64; median 54.50; and the mode was 56.00. The standard deviation of Indonesian speaking skills in the control class is 4,304. Based on Table 02. it can be concluded that the most score obtained by students in the pre-test of Indonesian speaking skills in the control group lay in a score of 56.00 as many as nine students (40.90\%). In contrast, the data post-test of the Bahasa speaking skills control group showed that the average maximum value of post-test is 80.00 and the minimum value is 50.00 . The average post-test score is 65.50; median of 66.00 and mode of 66.00. The standard deviation of Indonesian speaking skills is 7,386 . The conclusion obtained that most post-test Indonesian speaking skills in the control group lie in a score of 66.00 as many as 5 students $(22.72 \%)$. Data pre-Test Bahasa speaking skills experiment group using role-playing shows that the average maximum value of pre-test was 63.00 and the minimum value is 47.00. The average pre-test score was 52.33; the median is 50.00; and 56.00 mode. The standard deviation of Indonesian speaking skills is 4,613. The conclusion that the value of pre-test mode of Indonesian speaking skills in the experimental group that received treatment using role-playing was located at a score of 56.00 as many as 8 students (33.33\%). While the data showed that the average maximum value of post-test in the experiment class using role-playing was 85.00 , and the minimum value is 59.00. The average post-test score was 73.79; the median is 73.50; and 66.00 mode. The standard deviation of Bahasa speaking skills in experimental classes using role-playing is 7,706. The mode score in post-test in the experimental group using role-playing learning can be concluded that the score lay in a score of 66.00 as much as 6 students $(25.00 \%)$.

Data analysis in this study consists of two parts, namely data analysis for the prerequisite test and data analysis for the research hypothesis test. As a condition to perform data analysis, it must be done prerequisites of data analysis, namely by calculating normality and homogeneity calculation. The calculation of the normality of each research variable was intended to know the data of each variable derived from a normally distributed population. Normality calculations were performed to measure pretest and post-test of students' Indonesian speaking skills in the experimental group who received treatment using role-playing and control groups using conventional learning models. The testing criteria used to measure the normality of the population in this study was if Asymp. Sig > of the alpha value specified $\alpha=0.05$, and the data was abnormal if Asymp. Sig < of the alpha level set $\alpha=0.05$. Normality testing was calculated using Kolmogorov-Simirmov with the help of SPSS 16.0 software for the windows program. The probability significance value ( $\mathrm{p}$-value) was greater than, and the population is not normally distributed if the $p$-value was less than the significance of $\alpha=0.05$. The results of the normality calculation using SPSS 16.0 for windows can be seen in Table 3.

Table 3. Normality Calculation Results

\begin{tabular}{lllll}
\hline \multirow{2}{*}{$\begin{array}{c}\text { Analyst } \\
\text { Results }\end{array}$} & \multicolumn{1}{c}{ Variable } & \multicolumn{2}{c}{ Kolmogorov } & \multirow{2}{*}{ Conclusion } \\
\cline { 3 - 4 } Control & Pre-test Bahasa Speaking Skill & 0,254 & 0,255 & Normal \\
& Post-test Bahasa Speaking Skill & 0,196 & 0,186 & Normal \\
\multirow{2}{*}{ Role Playing } & Pre-test Bahasa Speaking Skill & 0,200 & 0,235 & Normal \\
& Post-test Bahasa Speaking Skill & 0,128 & 0,157 & Normal \\
\hline
\end{tabular}


Based on Table 4 it can be seen that the significance value $>0.05$ stated that the data were normally distributed. The second prerequisite for data analysis was the calculation of homogeneity. This homogeneity calculation used an F or Levene test. This homogeneity calculation test is to test 4 data. Pretest data and post-test data on Indonesian speaking skills in the experimental group were treated using role-playing, and the control group using conventional learning models. The analysis of homogeneity calculation utilizing the help of SPSS 16.0 obtained a summary of the statistical value of the Levene test in Table 4.

Table 4. Homogeneity Calculation Result

\begin{tabular}{rrccc}
\hline No & Category & Levene Statistic & Asymp Sig. & Conclusion \\
\hline 1. & Pre-test Bahasa Speaking Skill & 0,009 & 0.991 & Homogenous \\
2. & Post-test Bahasa Speaking Skill & 0.627 & 0.537 & Homogenous \\
\hline
\end{tabular}

From Table 05. it can be known that the significance of Levene test results in the experimental group that received treatment using role-playing and the control group using conventional learning models had a significance value greater than $\alpha=0.05$. Based on this, it can be concluded that the variance of the third class is homogeneous. The next step of hypothesis testing using ANOVA, hypothesis There was a significant influence on applying role-playing type learning to the Bahasa speaking skills of grade IV elementary students. Decision-making and concluding hypothesis tests were conducted at a level of significance of 0.05 . The criteria used in the deduce retrieval was if the chance of an error $<0.05$; then the hypothesis nil $\left(\mathrm{H}_{0}\right)$ was rejected, and if the possibility of error $>0.05$; then the hypothesis nil $\left(\mathrm{H}_{0}\right)$ accepted. ANOVA test results on the variable Bahasa speaking skills obtained acalculated value of $\mathrm{F}$ of 30,536 and $\mathrm{p}=0.000<0.05$; then $\mathrm{H} 0$ can be rejected, so it can be concluded that there was a significant influence on the application of role-playing learning to the skills of Indonesian students in grade IV elementary school. The second hypothesis states that "there is a significant influence on applying role-playing learning to the Indonesian language speaking skills of grade IV elementary school students. ANOVA test results on variable Indonesian speaking skills obtained acalculated value of $F$ of 81,352 and $p=0,000<0.05$; then $\mathrm{H}_{0}$ can be rejected, so it can be concluded there was a significant influence on applying it role-playing learning to the Bahasa speaking skill grade IV elementary students.

\section{Discussion}

Descriptively, students' Indonesian speaking skills after implementing the role-playing learning model were higher than before the role-playing learning model was applied. This was because learning has optimized the role-playing model to the maximum. The indicators achieved were seen in almost all different indicators with Bahasa speaking skills before using the role-playing model. The implementation of a role-playing learning model influences students' Indonesian language speaking skills. This model encourages students to actively participate through discussion, role-playing, analysis, and working together to drive the course of role-playing learning. Participation is a manifestation of student behavior in learning activities that is the totality of a student's mental and emotional involvement to encourage them to contribute and be responsible for achieving a goal that is the achievement of satisfactory learning outcomes (Kristiana, 2020). An active, fun, and motivating learning model will affect students' learning outcomes (Nurhasanah et al., 2016; Suastika \&Rahmawati, 2019). Learning with role playing provided opportunities for students to be more active. This was necessary because it appeals to students and makes learning not feel boring. Students' understanding was awakened from the concepts tucked away in the story script if the students were able to absorb the material presented in the story well. Then students' Indonesian speaking skills were getting better.

Further findings found that there began to be courage in students to ask or express opinions directly either. The courage of the student to ask will certainly train the student's ability in the student's speaking skills. The use of role-playing models can organize students in group learning and measure the extent to which students' understanding of the understanding of organizing materials and measure the extent of students' abilities in the materials discussed. Students were allowed to prepare for role-playing sessions, and teachers only as mentors if they experience difficulties. With this model, learning was an opportunity for students to interact with each other and communicate with other students in the classroom. This can increase students' knowledge and boost social skills. This impacts improving students' Indonesian language speech skills (Cakra et al., 2016). Kegiatan learning can not be separated from the question and answer activities either between teachers with students or students with the students themselves. This was reflected by practicing speaking skills in students to convey a lesson 
through two-way interaction, namely from the teacher to the student and from the student to the teacher, to obtain material certainty through the oral answers of the teacher or students.

Further findings were also found in teachers who teach using role-playing learning models that teachers can be creative and fun facilitators for students and create more active learning. In the learning process using this model, teachers can direct students to be more active in asking questions, questioning, and expressing their opinions. The activeness of these students was very important in shaping students' Indonesian speaking skills (Kristiana, 2020). This happened after the implementation of the role-playing learning model. Teachers have a role as facilitators, motivators, and evaluators to all students, so that students can learn in a pleasant atmosphere, happy, energetic, not anxious, and dare to express their opinions openly (Prastowo, 2021). Some previous research that supports this research states that the use of role playing model in IPS learning affects social science students' motivation and learning outcomes (Wahyuni et al., 2018). Model role-playing learning positively affects the results of learning sciencev(Nurhasanah et al., 2016). In addition, role-playing models can improve students' speaking skills.

Based on the description, it was important to carry out this study because no researchers analyzed the influence of the role-playing learning models on Bahasa speaking skills. The findings of this study will have implications for improving students' Indonesian language speaking skills. The use of roleplaying learning model can be used to provide a pleasant learning atmosphere for students to give meaningful lessons for students so that it can provide good solutions in learning activities to improve students'Indonesianspeaking skills. In addition, role-playing can improve students' Indonesian speaking skills in following the learning.

\section{CONCLUSION}

Role-playing model learning influences students' Bahasa speaking skills. There needs to be an improvement of skills in applying role-playing type learning in a way often used in learning to achieve optimal learning objectives. Students should always strive to improve their Indonesian language speaking skills in the classroom so that the learning takes place optimally because, in learning, students did not play a passive role but play an active role

\section{REFERENCES}

Aditya Dharma, I. M. (2019). Pengembangan Buku Cerita Anak Bergambar Dengan Insersi Budaya Lokal Bali Terhadap Minat Baca Dan Sikap Siswa Kelas V Sd Kurikulum 2013. Journal for Lesson and Learning Studies, 2(1), 53-63. https://doi.org/10.23887/jlls.v2i1.17321.

Ariani, T. (2020). Analysis of Students' Critical Thinking Skills in Physics Problems. Physics Educational Journal, 3(1), 1-13. https://doi.org/10.37891/kpej.v3i1.119.

Cakra, G., Dantes, N., Widiartini, K., Pendidikan, E., Pasca, P., \& Universitas, S. (2016). Pengaruh Penggunaan Metode Pembelajaran Bermain Peran Terhadap Sikap Sosial Dan Kemampuan Berbicara Bahasa Indonesia Siswa Kelas Vi Sd N 29 Dangin Puri Tahun Pelajaran 2014 / 2016. EJournal Program Pascasarjana Universitas Pendidikan Ganesha, 5(1), 1-10. https://doi.org/10.23887/jpepi.v5i1.1579.

Chan, F., Kurniawan, A. R., Nurmaliza, Herawati, N., Efendi, R. N., \& Mulyani, J. S. (2019). Strategi Guru Dalam Mengelola Kelas di Sekolah Dasar. Internasional Journal of Elementary Education, 3(4), 439446. https://doi.org/10.23887/ijee.v3i4.21749.

Diah Purwati, N. L. P., Wibawa, I. M. C., \& Margunayasa, I. G. (2019). Pengaruh Numbered Head Together Berbantuan Gambar Terhadap Penguasaan Kompetensi Pengetahuan IPA. Jurnal Pedagogi Dan Pembelajaran, 2(3), 282. https://doi.org/10.23887/jp2.v2i3.19275.

Hussain, S. (2017). Teaching Speaking Skills in Communication Classroom. International Journal of Media, Journalism and Mass Communications, 3(3), 14-21. https://doi.org/10.20431/2454-9479.0303003.

Korsgaard, M. ., Larsen, V., \& Wiberg, M. (2020). Thinking and Researching Inclusive Education Without a Banister - Visiting, Listening and Tact as a Foundation for Collective Research on Inclusive Education. International Journal of Inclusive Education, 24(5), 496-512. https://doi.org/10.1080/13603116.2018.1469680.

Kristiana, A. A. I. D. (2020). Meningkatkan Keterampilan Berbicara Siswa Melalui Model Pembelajaran Role Playing Berbantuan Media Audio Visual. Jurnal Mimbar Ilmu, 25(3), 449-459. https://doi.org/10.23887/mi.v25i3.26388.

Kristin, F. (2018). Meta-Analisis Pengaruh Model Pembelajaran Role Playing Terhadap Hasil Belajar IPS. Refleksi Edukatika : Jurnal Ilmiah Kependidikan. https://doi.org/10.24176/re.v8i2.2356.

Lim, J., \& Polio, C. (2020). Multimodal Assignments in Higher Education: Implications for Multimodal 
Writing Tasks for L2 Writers. Journal of Second Language Writing, 47. https://doi.org/10.1016/j.jslw.2020.100713.

Lubis, A. . (2020). Corpus-driven Genre Pedagogy of English for Research Publication Purposes: Toward an Elf-referenced Critical Teaching Framework. International Journal of Education, 12(2), 109-121. https://doi.org/10.17509/ije.v12i2.19429.

Mishbah, U., Putri, S. ., \& Zakirman. (2020). Permainan Ludo untuk Meningkatkan Keterampilan Kolaborasi Siswa dalam Pembelajaran Matematika. Internasional Journal of Elementary Education, 4(1), 130-138. https://doi.org/10.23887/ijee.v4i2.23050.

Nita, O. (2019). Hubungan Kreativitas Dengan Hasil Belajar Bahasa Indonesia. Jurnal KIBASP, 3(1), 92-103. https://doi.org/10.31539/kibasp.v3i1.903.

Nungki Heriyati, Riris K. Sarumpaet, C. T. S. (2020). Speaking Through Silence: Trauma in Literary Worko Title. Proceedings of the International Conference on Business, Economic, Social Science, and Humanities - Humanities and Social Sciences Track (ICOBEST-HSS 2019), 391. https://doi.org/10.2991/assehr.k.200108.037.

Nurhasanah, I. A., Sujana, A., \& Sudin, A. (2016). Penerapan Metode Role Playing Untuk Meningkatkan Hasil Belajar Siswa Pada Materi Hubungan Mahluk Hidup Dengan Lingkungannya. Jurnal Pena Ilmiah, $1(1)$,

611-620. https://ejournal.upi.edu/index.php/penailmiah/article/download/2992/2059.

Prastowo, A. (2021). Peran Guru dalam Perencanaan Pembelajaran Berbasis Aplikasi Zoom Meeting di Sekolah Dasar. Jurnal Ilmu Pendidikan, 3(4), 1734-1744. https://doi.org/10.31004/edukatif.v3i4.654.

Priyantini, L. D. E. (2020). Pengaruh Kegiatan Literasi Dan Read Aloud Terhadap Keterampilan Bahasa Reseptif Anak Usia Dini. http://lib.unnes.ac.id/40920/1/tesis full.pdf.

Rambe, A. M., Sumadi, T., \& Meilani, R. S.. M. (2021). Peranan Storytelling dalam Pengembangan Kemampuan Berbicara pada Anak Usia 4-5 Tahun. Jurnal Obsesi : Jurnal Pendidikan Anak Usia Dini, 5(2), 2134 - 2145. https://doi.org/10..31004/obsesi.v5i2.1121.

Rambe, R. N. K. (2018). Penerapan Strategi Index Card Match Untuk Meningkatkan Hasil Belajar Siswa Pada Mata Pelajaran Bahasa Indonesia. Jurnal Tarbiyah : Jurnal Ilmiah Kependidikan, 25(1), 93-124. https://doi.org/10.30829/tar.v25i1.237.

Setiawan, E. (2019). Efforts To Increase Speaking0skills In Front Of The Class With Role Playing Techniques In Group Counseling Service For Students In Class VII B SMP Negeri 21 Banjarmasin. Jurnal Pelayanan Bimbingan Dan Konseling, 2(2), 155-161. http://ppjp.ulm.ac.id/journals/index.php/jpbk/article/view/3410/2610.

Suastika, I. ketut, \& Rahmawati, A. (2019). Pengembangan Modul Pembelajaran Matematika Dengan Pendekatan Kontekstual. JPMI (Jurnal Pendidikan Matematika Indonesia), 4(2), 58. https://doi.org/10.26737/jpmi.v4i2.1230.

Sulianto, J., Purnamasari, V., \& Febriarianto, B. (2019). Pengaruh Model Pembelajaran Think-Pair-Share terhadap Hasil Belajar Siswa Kelas V (Lima) Materi Organ Tubuh Manusia dan Hewan. Internasional Journal of Elementary Education, 3(2), 124-131. https://doi.org/10.23887/ijee.v3i2.18515.

Syukur, A., Azis, R., \& Sukarsih. (2020). Developing Reading Learning Model to Increase Reading Skill for Animal Husbandry Students in Higher Education. Britain International of Linguistics, Arts and Education, 2(1), 484-493. https://doi.org/10.33258/biolae.v2i1.220.

Wahyuni, I., Slameto Slameto, \& Setyaningtyas, E. W. (2018). Penerapan Model PBL Berbantuan Role Playing untuk Meningkatan Motivasi dan Hasil Belajar IPS. Jurnal Ilmiah Sekolah Dasar, 2(4), 356363. http://dx.doi.org/10.23887/jisd.v2i4.16152. 